Dzgoeva Madina Georgievna, MD, PhD, Professor, Head of the Department of dentistry № 1 ; tel.: +79188232325; e-mail: madina-dzgoeva@mail.ru; https://orcid.org/0000-0002-0247-1901

Sirak Sergey Vladimirovich, MD, PhD, Professor, Head of the Department of dentistry;

tel.: +78652350551; e-mail: sergejsirak@yandex.ru; https://orcid.org/0000-0002-4924-5792

Bitarov Pavel Alanovich, postgraduate student;

tel.: +79888777087; e-mail: pavel.bitarov@mail.ru; https://orcid.org/0000-0002-2212-0316

Sirak Alla Grigorievna, MD, PhD, Professor, Head of Departament of histology; tel.: +78652356219; e-mail: kafedragist@yandex.ru

Tingaeva Yulia Igorevna, resident;

tel.: +79272744000; e-mail: iulia.tingaeva@yandex.ru; https://orcid.org/0000-0001-8471-0146

Andreev Anton, Senior Laboratory Assistant of the Department of dentistry; tel.: +78652350551; e-mail: andreev_ant22@yandex.ru

(c) Group of authors, 2021

UDC 616.31-089

DOI - https://doi.org/10.14300/mnnc.2021.16040

ISSN - 2073-8137

\title{
MODIFICATIONS OF THE SPLIT BONE TECHNIQUE FOR LATERAL RIDGE AUGMENTATION
}

\author{
Muraev A. A. ${ }^{1}$, Polevoy V. V. ${ }^{2}$, Ivanov S. Yu. ${ }^{1,3}$, Dolgalev Al. Al. ${ }^{4}$, \\ Muhametshin R. F. ${ }^{1}$, Gazhva S. I. ${ }^{5}$, Boyko E. M. ${ }^{4}$, Zelensky V. I. ${ }^{4}$ \\ ${ }^{1}$ Peoples' Friendship University of Russia, Moscow, Russian Federation \\ ${ }^{2}$ Central Clinical Hospital of the Presidential Administration of Russian Federation, \\ Moscow, Russian Federation \\ ${ }^{3}$ I. M. Sechenov First Moscow State Medical University (Sechenov University), \\ Russian Federation \\ ${ }^{4}$ Stavropol State Medical University, Russian Federation \\ ${ }^{5}$ Privolzhsky Research Medical University, Nizhny Novgorod, Russian Federation
}

\section{МОАИФИЦИРОВАННЫЕ МЕТОАЫ МЕЖКОРТИКААЬНОЙ ОСТЕОТОМИИ И РАСЩЕПАЕНИЯ ААЬВЕОАЯРНОГО ГРЕБНЯ}

\author{
А. А. Мураев ${ }^{1}$, В. В. Полевой ${ }^{2}$, С. Ю. Иванов ${ }^{1,3}$, А. А. Аолгалев 4 , \\ Р. Ф. Мухаметшин ${ }^{1}$, С. И. Гажва ${ }^{5}$, Е. М. Бойко ${ }^{4}$, В. И. Зеленский ${ }^{\prime}$
}

${ }^{1}$ Российский университет Аружбы народов, Москва, Российская ФеАерация

2 Центральная кАиническая больница ААминистрации ПрезиАента

Российской ФеАерации, Москва, Российская ФеАерация

3 Первый Московский госуАарственный меАицинский университет им. И. М. Сеченова (Сеченовский Университет), Российская ФеАерация

${ }^{4}$ Ставропольский госуАарственный меАицинский университет, Российская ФеАерация

5 Приволжский научно-исслеАоватеАьский МеАицинский Университет Министерства зАравоохранения Российской ФеАерации, Нижний НовгороА, Российская ФеАерация

This article presents a modified approach to the method of intercortical osteotomy and splitting of the alveolar ridge for use when the classical approach does not solve the problem of atrophy. The standard protocol for osteotomy with alveolar ridge splitting is not universal for all clinical situations. We operated on 33 patients using five modifications for splitting the alveolar ridge: lingual, vestibular and lingual, mesial, rotation of the bone block by $180^{\circ}$, and lingual with displacement of the osteotomy line.

In all cases, the alveolar ridge width reached $7.1 \pm 0.7 \mathrm{~mm}$, sufficient for installation of dental implants with a regular or wide platform $(3.75-5.0 \mathrm{~mm}$ ), and only $6.1 \%$ of implants failed. Based on the biological principles of alveolar bone regeneration, the indications for the use of intercortical osteotomy and splitting of the alveolar ridge have been expanded for use in various clinical situations.

Keywords: dental implants, alveolar bone loss, sticky bone, ridge-split technique, alveolar ridge augmentation, piezoelectric bone surgery, bone tissue grafts

Представлены модифицированные подходы метода межкортикальной остеотомии и расщепления альвеолярного гребня, когда классический подход не позволяет решить проблему атрофии. Поскольку стандартный протокол проведения остеотомии с расщеплением альвеолярного гребня не является универсальным для всех клинических ситуаций. Нами были прооперированы 33 пациента с применением 5 различных модификаций расщепления альвеолярного гребня: оральный, вестибулярный и оральный, мезиальный, с ротацией костного блока на $180^{\circ}$, язычный со смещением линии остеотомии. 


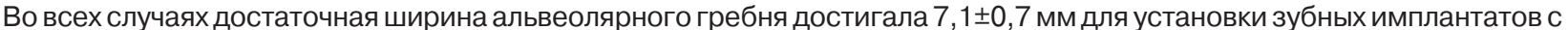
обычной или широкой платформой (3,75-5,0 мм). Количество потерянных имплантатов составило 6,1 \%. Таким образом, основываясь на биологических принципах регенерации альвеолярной кости, успешно удалось расширить показания к применению межкортикальной остеотомии и расщеплению альвеолярного гребня в различных клинических ситуациях.

Ключевые слова: дентальная имплантация, атрофия альвеолярной кости, расщепление гребня, увеличение альвеолярного гребня, трансплантаты костной ткани

For citation: Muraev A. A., Polevoy V. V., Ivanov S. Yu., Dolgalev Al. Al., Muhametshin R. F., Gazhva S. I., Boyko E. M., Zelensky V. I. MODIFICATIONS OF THE SPLIT BONE TECHNIQUE FOR LATERAL RIDGE AUGMENTATION. Medical News of North Caucasus. 2021;16(2):176-180. DOI - https://doi.org/10.14300/mnnc.2021.16040

Для цитирования: Мураев А. А., Полевой В. В., Иванов С. Ю., Долгалев А. А., Мухаметшин Р. Ф., Гажва С. И., БойКО Е. М., ЗеЛЕНСКИЙ В. И. МОДИФИЦИРОВАННЫЕ МЕТОДЫ МЕЖКОРТИКАЛЬНОЙ ОСТЕОТОМИИ И РАСЩЕПЛЕНИЯ АЛЬВЕОЛЯРНОГО ГРЕБНЯ. Медицинский вестник Северного Кавказа. 2021;16(2):176-180.

DOI - https://doi.org/10.14300/mnnc.2021.16040

Ridge split - RS

СBCT - cone-beam computed tomography

T he generally accepted technique of intercortical osteotomy with alveolar ridge splitting (RS) involves the use of a vestibular cortical block, which is tilted with an axis of rotation at the base, thereby increasing the width of the alveolar ridge. The resulting space is filled with a graft, the reconstruction area is covered with a collagen membrane, and the wound is sutured [1, 2]. Even though this protocol is well developed, it has several disadvantages.

First, if the initial width of the alveolar bone is less than $2 \mathrm{~mm}$, splitting is not recommended [3]. When the width of the cortical plate is less than $1 \mathrm{~mm}$, resorption occurs. Second, splitting in the vestibular direction is not always necessary; if the loss of alveolar bone width occurs on the lingual side, recovery will be directed in the same direction, which is not provided for by the standard protocol.

This paper describes modified methods of splitting the alveolar ridge, which make it possible to perform this operation at any initial width of the alveolar bone, taking into account the vector of horizontal atrophy.

Material and Methods. Thirty-three patients with alveolar bone width deficiency were included in this study. All patients were generally healthy and were nonsmokers. Patients were divided into groups depending on the initial width of the alveolar ridge and the direction of the atrophy vector: from the lingual or vestibular side. The initial alveolar ridge thickness was $2.4 \pm 1.4 \mathrm{~mm}$, with a height of $11 \pm 2.6 \mathrm{~mm}$. Clinical and digital computerized methods were used to determine the direction of alveolar bone atrophy. The palpation method is not accurate enough, because the thickness of the mucous membrane, especially in the maxilla, hides the thickness of the bone. Therefore we used cone-beam computed tomography (CBCT) data to evaluate the initial width and determine whether the bone deficiency was lingual or vestibular. These were the determining factors in choosing the RS protocol.

Patients underwent modified RS techniques. In the mandible, the osteotomy was performed using the Piezotome Solo LED ultrasonic surgical device (ACTEON Group, La Marnasse, Olliergues, France); in the maxilla we used Sonosurgery® Inserts (Pesaro, Italy). Microscopic screws $1.2 \mathrm{~mm}$ in diameter and 8, 10, or $12 \mathrm{~mm}$ long (Conmet, Moscow, Russia) were used to fix the bone blocks. The bone defects were filled with SureOss allogenic bone (HansBiomed, Seoul, South Korea), and the reconstruction area was covered with a collagen membrane (BioplastDent, Belgorod, Russia). Before the wound was sutured, mucoperiosteal flaps were mobilized from the lingual and vestibular sides, and the periosteum on both flaps was brought together with inner mattress resorbable sutures (Vicryl 4-0, Ethicon, Somerville, NJ, USA). This method provided membrane fixation and covered the reconstruction area with periosteum. The edges of the mucosal flap were sutured with nonresorbable monofilament polyamide threads (Daclon 6-0, Futberg Minsk, Belarus). The sutures were removed 7-10 days post operatively.

Patients were allocated to five groups based on the surgical protocol used. In Group 1, the RS was performed in a lingual (palatal) direction; in Group 2, the RS was performed in both lingual and vestibular directions; and in Group 3 the RS was performed in vestibular and mesial directions. In Group 4, the bone block was rotated $180^{\circ}$ after vestibular RS; and in Group 5 (with initial width $<2 \mathrm{~mm}$ ), the upper line of the osteotomy was shifted downwards and lingually 1-2 $\mathrm{mm}$, and the splitting was performed in a vestibular direction.

Group 1 (lingual RS). This group included patients with horizontal atrophy of the alveolar ridge (AR) on the lingual side. The initial width of the AR was $2.8 \pm 0.7 \mathrm{~mm}$. At first, a vertical cut was made along the center of the AR to a depth corresponding to the level of the split, but maintaining a distance of at least $2 \mathrm{~mm}$ up to the lower jaw channel (or sinus floor). The length of the osteotomy corresponded to the length of the narrowed part of the alveolar bone. The cortical layer was then osteotomized downward from the edges of the horizontal cut on the lingual side, again to the height that corresponded to the level of cleavage. Finally, the lower edges of the vertical lines were connected by cutting the cortical plate to a depth of no more than $1 \mathrm{~mm}$. This osteotomy line defined the level of fracture and rotation of the lingual bone block. Then the RS was progressively implemented using bone expanders of increasing diameter $(1.2 ; 2.3 ; 3.2 ; 3.8$; and $4.2 \mathrm{~mm})$. The displaced block was then fixed with microscrews to the vestibular cortical plate. Sharp bone edges were smoothed out, and the bone defect was filled with biomaterial and covered with a membrane. The wound was then sutured (Fig. 1).

Group 2 (lingual and vestibular $R S$ ). Patients with horizontal atrophy of the AR on the oral and vestibular sides were included in this group. The initial width of the alveolar base was $3.2 \pm 0.6 \mathrm{~mm}$. The surgical protocol consisted of a combination of a classical RS and RS in the lingual direction as described for Group 1 (Fig. 2).

Group 3 (mesial RS). Patients with irregular horizontal atrophy on the vestibular side in the area of the premolars and molars were included in this group. The initial width of the $A R$ in the premolar region was $2.4 \pm 0.4 \mathrm{~mm}$, and the 

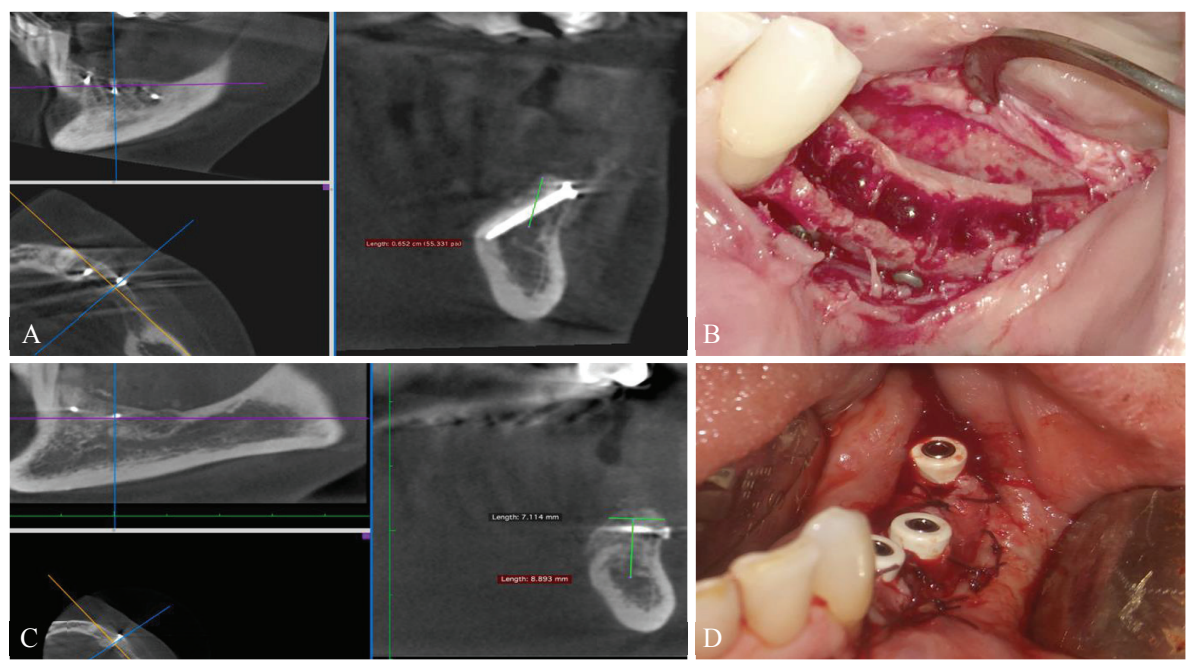

Fig. 1. Stages of oral RS: A - CBCT before the operation,

multi-planar reformation; B - Stage of operation. Splitting and displacement of the cortical block was performed lingually, fixation with microscrews

to the vestibular plate; C - CBCT 3 months after reconstruction, multi-planar reformation; D - Stage of implantation: implants and healing abutments are placed, mucous membrane flap is displaced apically and fixed with sutures
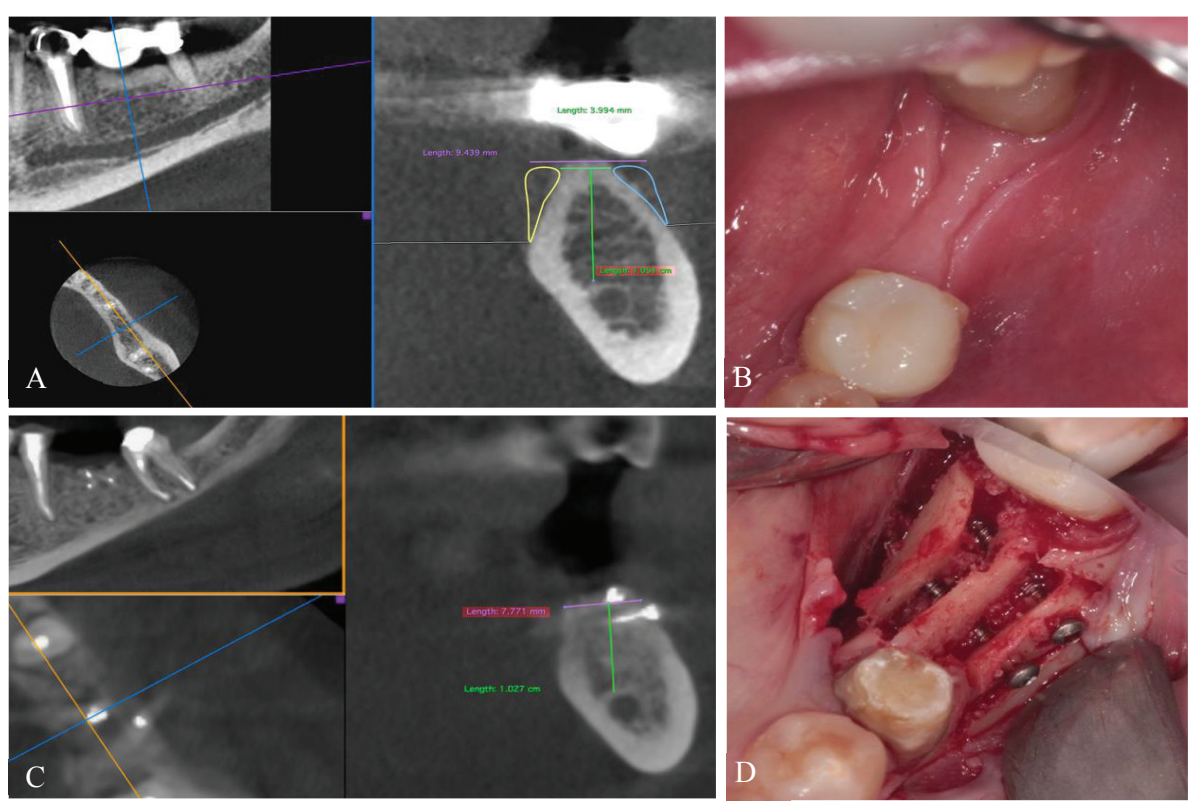

Fig. 2. Stages of oral and vestibular RS: A - CBCT before operation,

multi-planar reformation; $\mathrm{B}$ - Alveolar ridge before the operation;

C - CBCT 4 month after reconstruction; D - Stage of operation.

Splitting and displacement of the cortical block was performed lingually, fixation by microscrews to the vestibular plate block was firmly fixed with microscrews, the free space was filled with biomaterial and covered with a membrane, and the wound was sutured layer by layer.

Group 5 (RS after lingual shift). Patients with horizontal vestibular atrophy of the AR were included in this group. The initial width of the AR was $1.4 \pm 0.6 \mathrm{~mm}$, and the height was more than $11 \mathrm{~mm}$. The protocol differed from the classical one in that the upper line of the osteotomy was shifted downwards and lingually by 1-2 $\mathrm{mm}$, and the split was performed in a vestibular direction. After displacement of the vestibular block, its edge was above the lingual edge. To level out this discrepancy, the lower line of the osteotomy was expanded downwards and the block also shifted downwards. The block was firmly fixed with microscrews, the free space was filled with biomaterial and covered with a membrane, and the wound was sutured layer by layer (Fig. 4).

In all cases the implants were installed 4 months after reconstruction.

Results and Discussion. A total of 33 patients underwent surgery. In Group 1 (lingual RS) there were 10 patients (2 mandibular and 8 maxillary). Group 2 (lingual and vestibular RS) consisted of 3 patients, and Group 3 (mesial RS) consisted of 6 patients. In Group 4 (RS and $180^{\circ}$ bone block rotation) there were 5 patients, and in Group 5 (RS after lingual shift) there were 9 patients. Figures 1-30 show the initial CBCT images, the main stages of the surgery, CBCT images at 4 months after reconstruction, and panoramic radiographic images after implantation.

In all cases, an adequate width of $A R$ was achieved $(7.1 \pm 0.7 \mathrm{~mm})$ ridge was gradually expanded to a width of $7.1 \pm 0.7 \mathrm{~mm}$ in the molar zone. The surgical protocol was still a classical RS; however, no vertical osteotomy in the distal section was carried out. The bone fragment was «bent» from the mesial side, remaining attached distally, and was fixed with two microscrews. The graft filled the bone space and the reconstruction area was covered with a membrane. The wound was sutured layer by layer (Fig. 3).

Group 4 ( $R S$ and $180^{\circ}$ rotation). The initial width of the $A R$ in patients of this group was $2.4 \pm 0.3 \mathrm{~mm}$. The osteotomy was performed in accordance with the classical protocol, except that the lower line was 2-3 mm longer than the upper line. Thus, the block had a trapezoid form. The block was separated and turned $180^{\circ}$ upwards and fixed with microscrews. Thus, the upper edge of the block was wider than the bone defect and completely overlapped it. The

for placing dental implants with a regular or wide platform (3.75-5.0 mm). Only two implants failed. In this study we did not estimate the level of intraoral implant resorption, because the total number of reconstructions and implants installed was insufficient to obtain reliable statistical data.

The RS method has been proven as a reliable method for achieving adequate width of the alveolar ridge with long-term stability, which is reflected in many publications $[4,5]$. Different criteria for conducting RS have been proposed.

A study by Artifexova et al. [6] showed that the RS technique can be performed with an initial alveolar ridge width of at least $2 \mathrm{~mm}$. For smaller widths, the author recommended bone grafting or guided bone regeneration. However, the 5-year survival rate of the implants in Group 5 patients (with initial AR width of $1.4 \pm 0.6 \mathrm{~mm}$ ) was $96.5 \%$, 

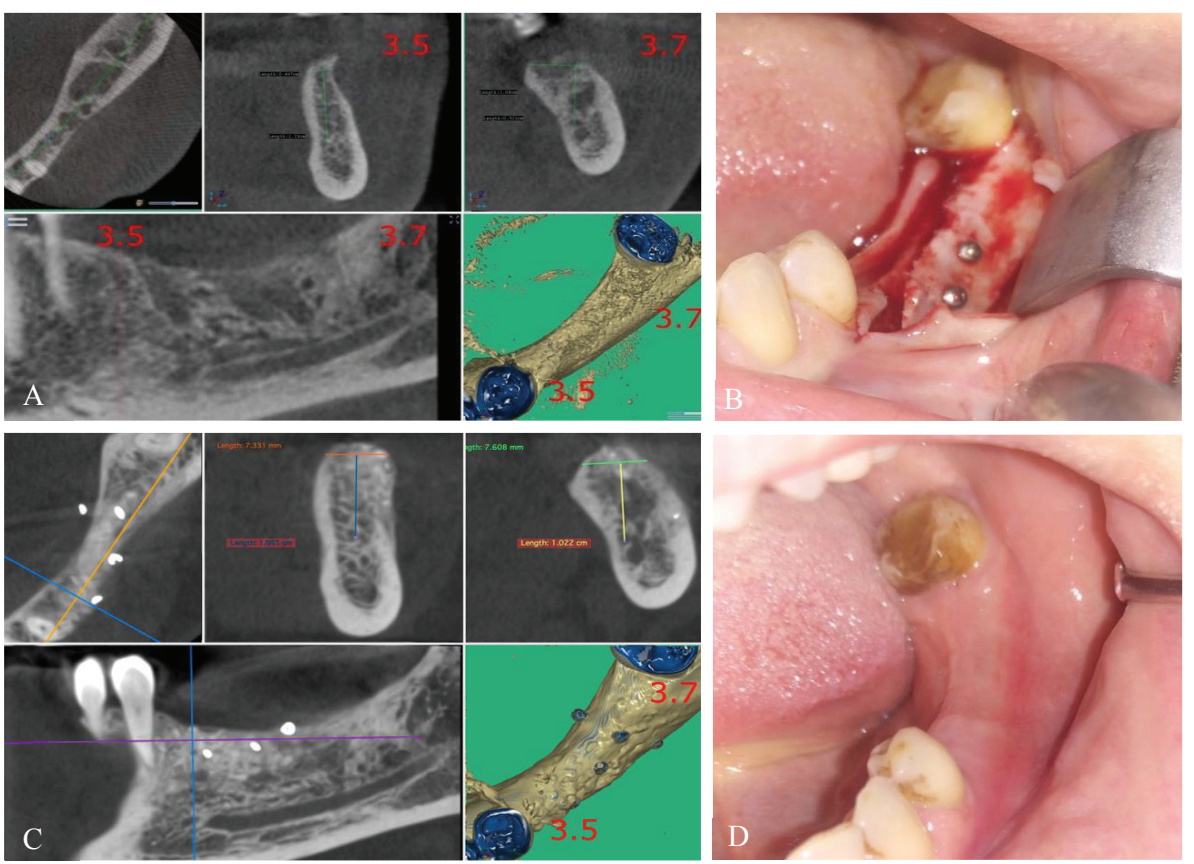

Fig. 3. Stages of mesial RS: A - CBCT before the operation, multi-planar and 3D reformation; B - The step of operation: cortical block is splitted and shifted vestibularly; rotation axis vertical and distal. The displaced block is fixed by microscrews to the lingual plate; C - 4 months post op; D - Intraoral view 4 months post op
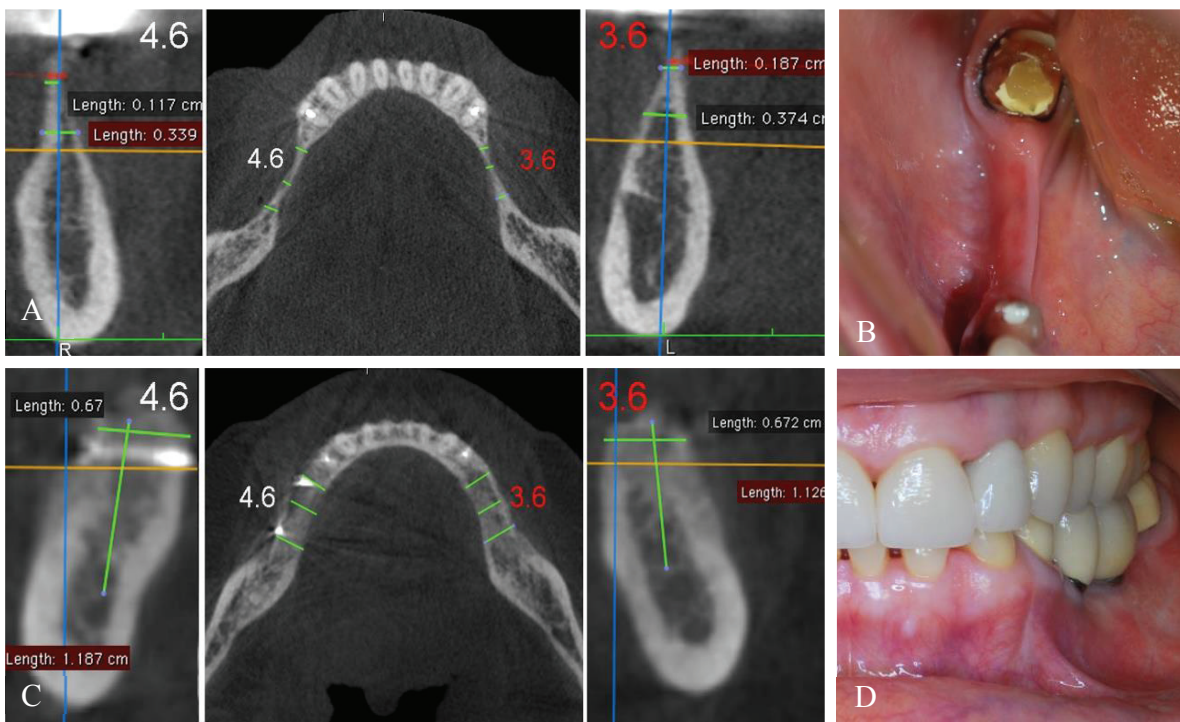

Fig. 4. Stages of RS after lingual shift: A - The initial CBCT;

$\mathrm{B}$ - Alveolar ridge in 3.5, 3.6, 3.7 teeth area; C - CBCT 4 month post Op: $\mathrm{D}$ - Prosthetic design 8 years after implantation and prosthetics which is consistent with the work of Zhusev [7], who found that the total osseointegration rate of implants 3 years after bone surgery was $96.4 \%$ in the maxilla and $98.5 \%$ in the mandible (97.53\% for all implants). The 10 -year intervals were $0.47 \mathrm{~mm}$ (standard deviation $0.91 \mathrm{~mm}$ ) and $1.93 \mathrm{~mm}$ (standard deviation $0.93 \mathrm{~mm}$ ) respectively.

In the mandible, implantation after a previously performed RS is a reliable method, with a high level of implantation success comparable to implantation with initially sufficient bone volume. These data are consistent with those of other studies [8].

We suggest that one of the reasons for the high success rate of RS is the formation of an organotypic structure in the alveolar ridge with external cortical and inner sponge layers, which is visible in the transverse CBCT slices. Another important factor that contributes to successful bone regeneration is the tight alignment of the periosteum with the displaced cortical blocks and the overlap of the periosteum with the bone gap. The periosteum ensures the germination of blood vessels and provides access to the cells involved in bone regeneration [9]. To avoid exfoliation of the periosteum during dental implant installation, we were careful to remove the microscrews through small relaxing incisions in the gingival mucosa above the screw head.

Conclusions. Alveolar ridge splitting is a reliable method for reconstructing the width of the alveolar ridge in the maxilla and mandible. The presented modifications of the classical protocol have expanded the indications for the RS technique to increase the width of the alveolar bone.

Disclosures: The authors declare no conflict of interest.

Acknowledgements. We thank Helen Jeays, BDSc AE, from Edanz (www.edanz.com/ac) for editing a draft of this manuscript.

\section{References}

1. Tolstunov L., Hicke B. Horizontal augmentation through the ridge-split procedure: a predictable surgical modality in implant reconstruction. Journal of Oral Implantology. 2013;39(1):59-68.

https://doi.org/10.1563/AAID-JOI-D-12-00112

2. Ananyan S. G., Zakaryan A. V., Gun'ko M. V., Gvetadze S. R. Intercortical osteotomy of alveolar bone in dental implantology. Stomatologiia. 2016;95(2):63-7. https://doi.org/10.17116/stomat201695263-67
3. Artifexova A. A., Ivanov, S. Y., Muraev A. A., Yancen I. E., Hasianov I. G. Clinical and morphological estimation of efficiency of reconstructive bone and plastic operations on the alveolar part of the jaw. J. Russian bulletin of dental implantology. 2012;2(26):74-78.

4. Moukrioti J., Al-Nawas B., Kreisler M. Evaluation of the split bone technique for lateral ridge augmentation: A retrospective case-control study. International Journal of Oral \& Maxillofacial Implants. 2019;34(5):1152-1160. https://doi.org/10.11607/jomi.7470 
5. Garcez-Filho J., Tolentino L., Sukekava F., Seabra M., Cesar-Neto J. B. [et al.] Long term outcomes from implants installed by using split crest technique in posterior maxillae: 10 years of follow up. Clin. Oral Implants Res. 2015;26(3):326-331. https://doi.org/10.1111/clr.12330

6. Karan N. B., Akinci H. O. A novel approach for horizontal augmentation of posterior maxilla using ridge split technique. J. Craniofac. Surg. 2019;30(5):1584-1588. https://doi.org/10.1097/SCS.0000000000005124

7. Windisch P., Martin A., Shahbazi A., Molnar B. Reconstruction of horizontovertical alveolar defects. Presentation of a novel split-thickness flap design for guided bone regeneration: A case report with 5-year follow-up. Quintessence Int. 2017;48(7):535-547. https://doi.org/10.3290/j.qi.a38354

8. Zhusev A. I. Enhancement the alveolar crest (alveolar part) of the mandible by split technik. J. Parodontology. 2010;1(54):16-18.

9. Azevedo R. A., Matos F. S., Figueiredo L. M. G. Appositional bone graft tunneled. International journal of surgery case reports. 2017;33:143-147.

https://doi.org/10.1016/j.ijscr.2017.02.011

\title{
About authors:
}

Muraev Alexandr Alexandrovich, MD, DMSc, Associate Professor, Professor at the Department of oral and maxillofacial surgery, tel.: +79037110246; e-mail: muraev_aa@pfur.ru; https://orcid.org/0000-0003-3982-5512

Polevoy Vladimir Viktorovich, dental surgeon;

tel.: +790994000736; e-mail: dr.polevoy@mail.ru; https://orcid.org/0000-0002-3569-1265

Ivanov Sergey Yurievich, MD, DMSc, corresponding Member of the Russian Academy of Sciences, the Department of oral and maxillofacial surgery; tel.: +79057572424; e-mail: syivanov@yandex.ru; https://orcid.org/0000-0001-5458-0192

Dolgalev Aleksandr Aleksandrovich, MD, DMSc, Professor of the Department of dentistry of general practice and pediatric dentistry; tel.: +7-9624404861; e-mail: dolgalev@dolgalev.pro; https://orcid.org/0000-0002-6352-6750

Muhametshin Roman Flaridovich, PhD, Assistant of the Department oral and maxillofacial surgery; tel.: +79152163040; e-mail: mukhametshin-rf@rudn.ru; https://orcid.org/0000-0001-6975-7018

Gazhva Svetlana Iosifovna, MD, DMSc, Professor, Head of Department of dentistry; tel.: +79519056098; e-mail: stomfpkv@mail.ru; https://orcid.org/0002-6121-7145

Boyko Evgeny Mikhailovich, PhD postgraduate student of the Department of general dentistry and pediatric dentistry; e-mail: vgedentzub@yandex.ru

Zelensky Victor Ivanovich, PhD postgraduate of the Department of general and pediatric dentistry; tel.: +79288151411; e-mail: viktorzel@bk.ru; https://orcid.org/0000-0001-6757-2714

(C) Group of authors, 2021

UDC 612.392.6: 612.751.1: 616-092.9: 616.71-003.96

DOI - https://doi.org/10.14300/mnnc.2021.16041

ISSN - 2073-8137

\section{PATHOBIOCHEMICAL CHANGES IN THE HISTOLOGICAL STRUCTURE OF KIDNEYS WITH EXPERIMENTAL HYPERVITAMINOSIS D}

\author{
Bondar T. P. ' , Svetlitskiy K. S. ' , Svetlitskaya Yu. S. ${ }^{2}$, Botasheva V. S. ${ }^{1}$ \\ 1 Stavropol State Medical University, Russian Federation \\ 2 Regional Clinical Oncological Center, Stavropol, Russian Federation
}

\section{ПАТОБИОХИМИЧЕСКИЕ ИЗМЕНЕНИЯ ГИСТОАОГИЧЕСКОЙ СТРУКТУРЫ ПОЧЕК ПРИ ЭКСПЕРИМЕНТААЬНОМ ГИПЕРВИТАМИНОЗЕ D}

\author{
Т. П. Бонаарь ${ }^{1}$, К. С. Светлицкий ${ }^{1}$, Ю. С. Светлицкая ${ }^{2}$, В. С. Боташева ${ }^{1}$ \\ 1 Ставропольский госуАарственный меАицинский университет, \\ Российская ФеАерация \\ 2 Ставропольский краевой кАинический онкологический Аиспансер, \\ Российская Фелерация
}

This study focused on the nature and degree of pathobiochemical changes in kidney tissues from the post-lactation period of female rats and their offspring at different ages after exposure to hypervitaminosis D. The pathobiochemical cascade from hypervitaminosis D involved excessive calcium accumulation and was characterized by self-damage to cells and the development of hypoxia during gestation and lactation and in the post-lactation period in rats and their offspring. Hypervitaminosis D produced vascular disorders (plethora of vessels of the kidney, stasis and interstitial edema) leading to increased epithelial cell size and narrowing of the lumen of tubules. These disorders were combined with hyaline-droplet protein dystrophy of the convoluted tubules and fatty degeneration of the epithelium of collecting ducts. There were also multiple foci of hypereosinophilia and areas of calcification located in the vessel walls, glomeruli and tubules of kidneys.

Keywords: hypervitaminosis D, calcium, hypoxia, kidneys, experiment, epithelial cells 